\title{
Assessing land condition as a first step to achieving land degradation neutrality: A case study of the Republic of Srpska
}

\author{
Marijana Kapović Solomun ${ }^{\mathrm{a}, *}$, Nichole Barger ${ }^{\mathrm{b}}$, Artemi Cerda ${ }^{\mathrm{c}}$, Saskia Keesstra ${ }^{\mathrm{d}, \mathrm{e}}$, \\ Mihajlo Marković ${ }^{\mathrm{f}}$ \\ a Department of Silviculture, Faculty of Forestry, University of Banja Luka, Republic of Srpska, Bosnia and Herzegovina \\ ${ }^{\mathrm{b}}$ Department of Ecology and Evolutionary Biology, University of Colorado, United States \\ ${ }^{\mathrm{c}}$ Department of Geography, University of Valencia, Spain \\ ${ }^{\mathrm{d}}$ Soil, Water and Land Use Team, Wageningen Environmental Research, The Netherlands \\ e Civil, Surveying and Environmental Engineering, The University of Newcastle, Callaghan 2308, Australia \\ ${ }^{\mathrm{f}}$ Department of Soil, Physiology and Plant nutrition, Faculty of Agriculture, University of Banja Luka, Republic of Srpska, Bosnia and Herzegovina
}

\section{A R T I C L E I N F O}

\section{Keywords:}

LDN target

Trends

Indicators

Hot spots

Challenges

Opportunities

\begin{abstract}
A B S T R A C T
Land Degradation Neutrality (LDN) is a key voluntary and aspirational target of Sustainable Development Goal (SDG) 15 which urges countries to protect, restore and promote sustainable use of terrestrial ecosystems, sustainably manage forests, combat desertification, and halt and reverse land degradation and halt biodiversity loss. A first and critical important step in the implementation of LDN is assessing the current land condition using not only active restoration of degraded land, but also targeting land degradation drivers behind the land degradation process. In a first step to achieve these goals, countries were provided a global dataset for three sub-indicators of land degradation: land cover (LC), land productivity dynamics (LPD) and soil organic carbon (SOC). Here, we report on trends in these sub-indicators for the Entity Republic of Srpska (RS) as a part of Bosnia and Herzegovina, which is a key analysis to inform the frame of reference or baseline conditions for the region to evaluate LDN across this region. Global data for LC for the RS indicates a $0.5 \%$ loss of forests ( 6400 ha) over the time period from 2000 to 2010 . Of this area, 5000 ha were converted to cropland and an additional 1400 ha was converted to shrubs, grasslands and sparsely vegetated areas. LPD declined over $2.5 \%(63,500$ ha) of the region. SOC declined on land use changed areas by $15.6 \%\left(74,609 \mathrm{Mg} \mathrm{ha}^{-1}\right)$ over the same time period. Based on global data, we estimated that $3 \%$ of the country is in a degraded state. Based on interviews with local stakeholders in 31 local communities, the primary land degradation drivers were identified and validated by team experts. Depopulation and migration to urban centers were identified as the important underlying drivers of land degradation that most municipalities are facing. The most frequent direct drivers of land degradation across this region were land abandonment, floods, drought, erosion and urbanization. Land abandonment, more specifically, has resulted in conversion of agriculturally productive lands to lands dominated by a wide range of invasive species over the last 25 years. Continued land degradation is underpinned by the lack of understanding by stakeholders of the importance of land as a resource. In evaluating the status, trends and drivers of land degradation for this region, we have identified key areas or "hot spots" that may be targeted for restoration options and may be used to achieve LDN targets by 2030 .
\end{abstract}

\section{Introduction}

Land Degradation Neutrality (LDN) is a new concept of the Sustainable Development Goals (SDG) under the UN 2030 Agenda for Sustainable Development. This is a voluntary and aspirational target of SDG 15 which urges countries to protect, restore and promote sustainable use of terrestrial ecosystems, sustainably manage forests, combat desertification, and halt and reverse land degradation and halt biodiversity loss. In a recent paper, soil has been pointed out to be of high importance to realize many of the SDGs, and especially SDG 15 (Keesstra et al., 2016). LDN sets the ambitious goal of stabilizing or increasing the amount and quality of land resources necessary to support ecosystem functions and services and enhance food security across the globe by 2030 (UNCCD, 2014). A first and critical important step in

\footnotetext{
* Corresponding author.

E-mail address: marijana.kapovic-solomun@sf.unibl.org (M. Kapović Solomun).
} 


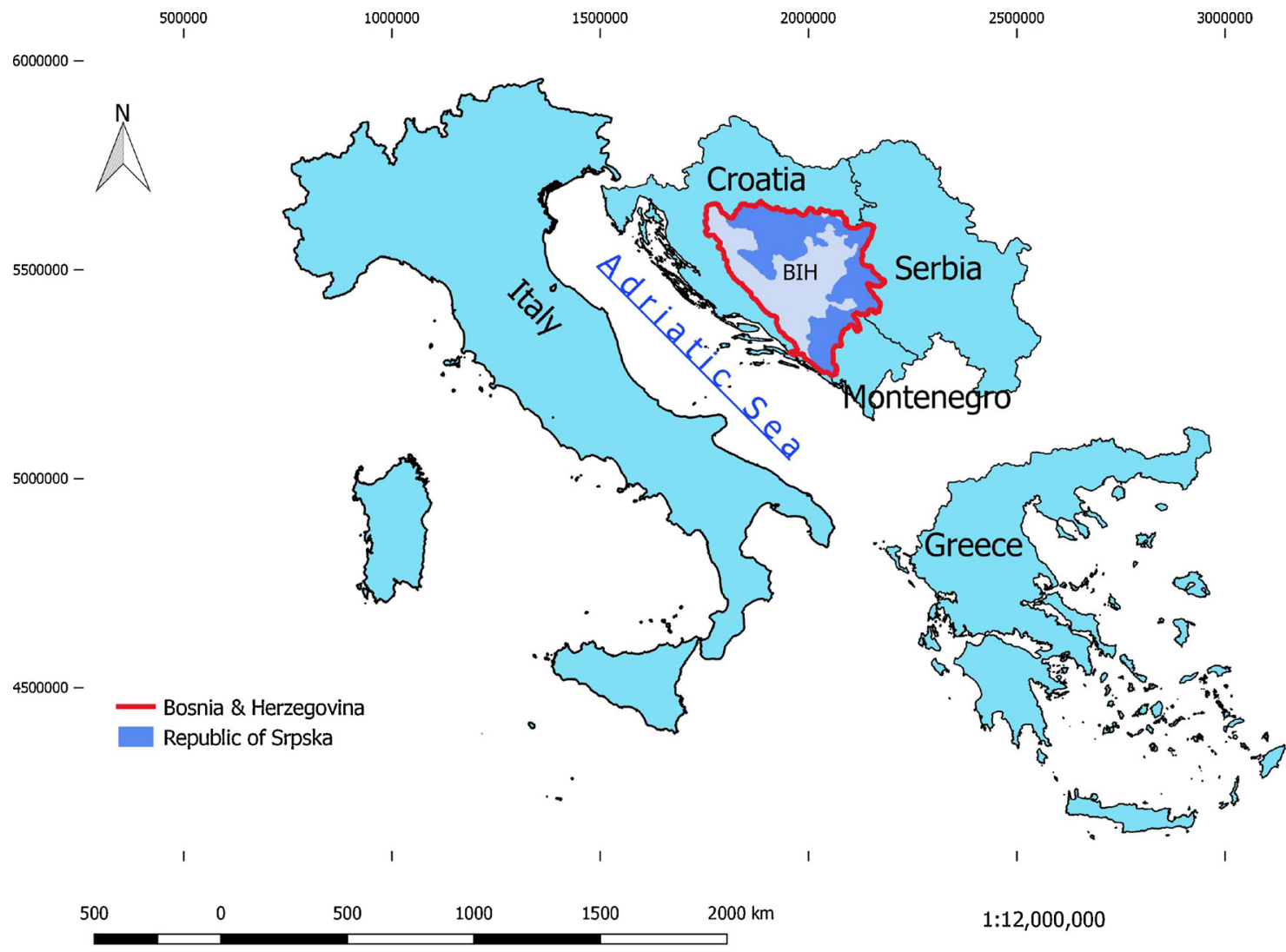

Fig. 1. Geographical location of the RS (BiH).

implementation of LDN is assessing current land condition using not only active restoration of degraded land, but also targeting land degradation drivers behind the land degradation process, such as unsustainable land practices, weak legal framework, lack of incentives, low level of awareness and others. UNCCD (2014) provided guidance (UNCCD, 2012, 2014, 2016, 2017) to countries which are invited to estimate state of land resources, trends of land degradation, and define national voluntary target and measures to achieve LDN by 2030 .

Bosnia and Herzegovina $(\mathrm{BiH})$ is a sovereign state with parliamentary state regulation and a decentralized political and administrative structure. The Republic of Srpska (RS) Entity is one of three administrative units regulated by the Dayton Peace Agreement. Land and land resources are under exclusive jurisdiction of the entities, therefore land is regulated by the Entity and not State legislation. Following this, diverse land use patterns, especially focused on forestry and agricultural, exist across the region for example, natural forests, forest plantations, cropland, pastures, meadows, orchards, vineyards, etc. An important and more recent driver of land use patterns over the last 25 years are migration and land abandonment due to land mines resulting from the Bosnian War of 1992 (Witmer and O'Loughlin, 2009).

$\mathrm{BiH}$ ratified the United Nations Convention to Combat Desertification in 2002, and the LDN target setting process began in 2016. Having recognized the importance of the LDN process, the Government of the RS voiced its interest in participating in the LDN process and took an early and leading role, which intensified interest of local stakeholders and decision makers in land planning, land management and land conservation. The important strategic document at the state level is the Action Program (AP) to Combat Land Degradation and Mitigate the Effects of Drought in Bosnia and Herzegovina (United Nations Environmental Programme (UNEP, 2017)), adopted in 2017 by the Council of Ministers of BiH. In accordance with the AP, the state of land resources is assessed, main pressures of land degradation are identified, and priorities to combat land degradation have been analyzed and defined. The RS is a very heterogeneous region in terms of climate, parent material, vegetation and land use patterns that, together with shortage of national data and lack of interest in LDN as a national priority, complicate the target setting process.

Existing national statistical data for land cover/use are not compliant with LDN land cover (LC) categories and relay on outdated cadastral data that local communities use for reporting to the Republic Institute of Statistics every year. The logical choice for the RS without reliable national data was to use global data for the LDN baseline, target and associate measures. $\mathrm{BiH}$, thus the RS, is a developing country in socio-economic transition, where land resources under active depopulation are a topic of a secondary importance. The legislative framework of the RS generally recognizes and respect sustainable land management where land protection is part of multiple sectoral regulations. However, LDN is not officially recognized by existing regulation/legislation. Policy and legal frameworks often mainstream sustainable land management (SLM) practices, but significant barriers exist for their effective implementation. Development and implementation of new SLM practices should build on existing local knowledge or, alternatively, regional experiences from similar conditions and environments (Cerdà et al., 2018; Motavalli et al., 2013; Schwilch et al., 2012; Liniger et al., 2011). Knowledge and awareness of decision makers is mostly insufficient, together with general public perception about land degradation, in spite of the increased frequency of extreme events caused by climate change, drought and floods, excessive and illegal deforestation, wildfires, urbanization, landslides and land contamination over the last 20 years. This paper describes the process of assessing land condition, as a fundamental requisite for LDN target setting. To this end, RS (BiH) is used as case study, and the paper identifies land degradation trends and drivers in the selected study area, and main gaps, challenges and opportunities for the implementation of the LDN target by 2030 in the RS. 


\section{Materials and methods}

\subsection{Site description}

The RS is located in Southeastern Europe, in the western Balkans (Fig. 1) and occupies a $25,024 \mathrm{~km}^{2}$ area within $\mathrm{BiH}$.

This region contains diverse climatic regimes which are characterized by a Mediterranean climate in the southwest, continental-mountain in the central and north region, and moderate continental climate in the remaining area (UNDP, 2016). In southwest region, due to the vicinity of Adriatic Sea, the average January temperatures are high (from 3 to $5{ }^{\circ} \mathrm{C}$ ), while summers are dry and hot and absolute maximum temperatures go up to $45^{\circ} \mathrm{C}$ (UNDP, 2016). Average annual amount of precipitation varies from 1000 to $2000 \mathrm{~mm}$. The central region of RS has a continental-mountain climate with severe winters (absolute minimum temperatures from -24 to $-34^{\circ} \mathrm{C}$ ), and warm summers (absolute maximum temperatures range from 30 to $36^{\circ} \mathrm{C}$ ). Average yearly precipitation ranges from 1000 to $1200 \mathrm{~mm}$ (UNDP, 2016). Snowfall is abundant especially in the higher elevation. The northern region has moderate continental climate with cold winters and warm summers but, in relation to the Alpine region, winter and summer temperature differences are smaller. In view of a blend of pedogenic factors, automorph and hydro-morph soils are developed in the territory of the RS. The most widespread soils are Mollic Leptosol, Haplic Cambisol and Leptic Cambisol according to WRB (WRB, 2006), while for hydromorph class, the most common are Haplic Planosols and Fluvisols (United Nations Environmental Programme (UNEP, 2017). The majority of soils in the territory of RS has a low plant and nutritional soil potential (Kapović Solomun et al., 2015).

\subsection{Indicator data}

Three global indicators of land based natural capital that are in current use by the UNCCD and recently proposed in the use of monitoring progress in the SDGs were provided to countries. Indicator data used in this analysis were: land cover (LC) over the period of 2000-2010 (European Space Agency, 2010), land productivity dynamics (LPD) over the period of 1999-2013 (JRC, 2016), soil organic carbon (SOC) for 2000 (ISRIC, (2010)) and methods are described in LDN Target Setting (TS) Technical guide (UNCCD, 2016). The baseline land condition of the RS was calculated based on LPD, as a sum of areas for all land cover categories with declining LPD, early signs of decline and stable but stressed LPD areas in 2010.

Land degradation drivers and degraded areas were surveyed within 31 local communities of the RS. LPD global datasets were used for prior identification of areas with decreased land productivity. Local communities with category 1, 2 and 3 (declined, early signs of decline and stable but stressed LPD) were visited with purpose to identify the main land degradation drivers and to validate degraded areas proposed by global data. A total of 279 detailed interviews were conducted in each of the 31 municipalities in the RS with the following local government participants: the Mayor, the Associate for Agriculture and Forestry, the Associate for Spatial Planning and Construction, and the Associate for the Economy. Representing the farming community, there was one farmer's association representative, two farmers (one woman), one private forest owner and one environmental non-governmental organization (NGO) representative.

Interviews focused on existing legislative and land planning at the local level (main knowledge gaps and barriers from different perspectives), identification of major LD drivers, existing incentives from local governments focused in land, and further needs of stakeholders. Questions and answers from the people who were interviewed are summarized in Table 1SI (Supplementary Information) and showed in $\%$ for answers.

Interviews were conducted in 2017 and aimed at gathering information to characterize the situation for the period 2000-2016.
Furthermore, each potentially degraded site within municipalities was visited by a team of experts (formed by Ministry of Agriculture, Forestry and Water management of the RS), who based on their professional experience identified the potential cause of degradation, and prioritized sites for further steps in terms of rehabilitation. Afterwards, degraded areas were presented and discussed with LDN working group members in terms of land productivity decrease, socio-economic importance for local community, type of land production (agriculture, forestry, mined areas, etc.) and main land degradation drivers. LDN working group consisted of nominated representatives of six land-related entity ministries, scientific and professional institutions, UNCCD National Focal point, Intergovernmental Panel on Climate Change (IPCC), (2006) national focal point, public forest enterprise, NGOs and representatives of local communities.

"Hot spots" were agreed upon by working group members and then presented to the Ministry of Agriculture, Forestry and Water management as locations of highest priority for land rehabilitation through implementation of sustainable land measures.

\section{Results and discussion}

Forests and forest lands of the RS occupy 53\% of the territory (Cadastre, 2016). Of this area, public forests cover $77 \%$ and private forests 23\%. According to national data (Statistical Journal, 2017), agricultural land in the RS covers $40 \%$ of the territory. Cultivated land occupies $81 \%$, where $71 \%$ of this area is under arable land and gardens, $23 \%$ meadows, $19 \%$ in pasture, and $6 \%$ in orchards (Table 1 ). The remaining $7 \%$ of the land area of the territory is in wetlands, water bodies, artificial areas and bare land (no national data about exact area).

The RS has 0.7 ha of agricultural land per inhabitant, 0.6 ha of cultivable land (arable land, garden, orchards, vineyards, meadows), but only 0.20 ha per inhabitant has been cultivated (The Basics, 2009), and $45.5 \%$ of the cropland has been abandoned in the last 25 years, resulting in prolific exotic species expansion. The majority of people are concentrated in local communities close to fertile agricultural land (Fig. 2A). In these areas where people are concentrated, there is a higher land cover change resulting in more severe degradation (Figs. 2A, 3 B).

\subsection{Assessing land condition}

Land cover (LC), land productivity dynamics (LPD) and soil organic carbon (SOC) were three indicators used to assess the current condition of the land (see Section 2.2). Land Cover data (Table 2) show a $0.5 \%$ decline in forests ( 6400 ha) over the time period from 2000 to 2010 . Of this forested area, $78 \%$ was converted to cropland (5000 ha) and $22 \%$ (1400 ha) to shrubs, grasslands and sparsely vegetated areas on (Fig. 3A). Land productivity increased across $82 \%$ of the RS region over the time period from 2000 to 2010 and declined on only $0.2 \%$ of the

Table 1

Land cover and land use in the Republic of Srpska in 2016 (Cadastre, 2016; Statistical Journal, 2017).

\begin{tabular}{lll}
\hline Land Cover/Land Use & Area (ha) & $\%$ \\
\hline Forests and forest land & $\mathbf{1 , 3 1 4 , 8 8 9}$ & $\mathbf{5 3}$ \\
Private & 303,672 & 23 \\
Public & $1,011,217$ & 77 \\
Agricultural land & $\mathbf{1 , 0 0 4 , 0 0 0}$ & $\mathbf{4 0}$ \\
Cultivated & 812,000 & 81 \\
Arable land gardens & 575,000 & 71 \\
Vineyards & 1000 & 0,1 \\
Meadows & 185,000 & 23 \\
Orchards & 51,000 & 6 \\
Pastures & 191,000 & 19 \\
Pools and fishponds & 1000 & 0,01
\end{tabular}



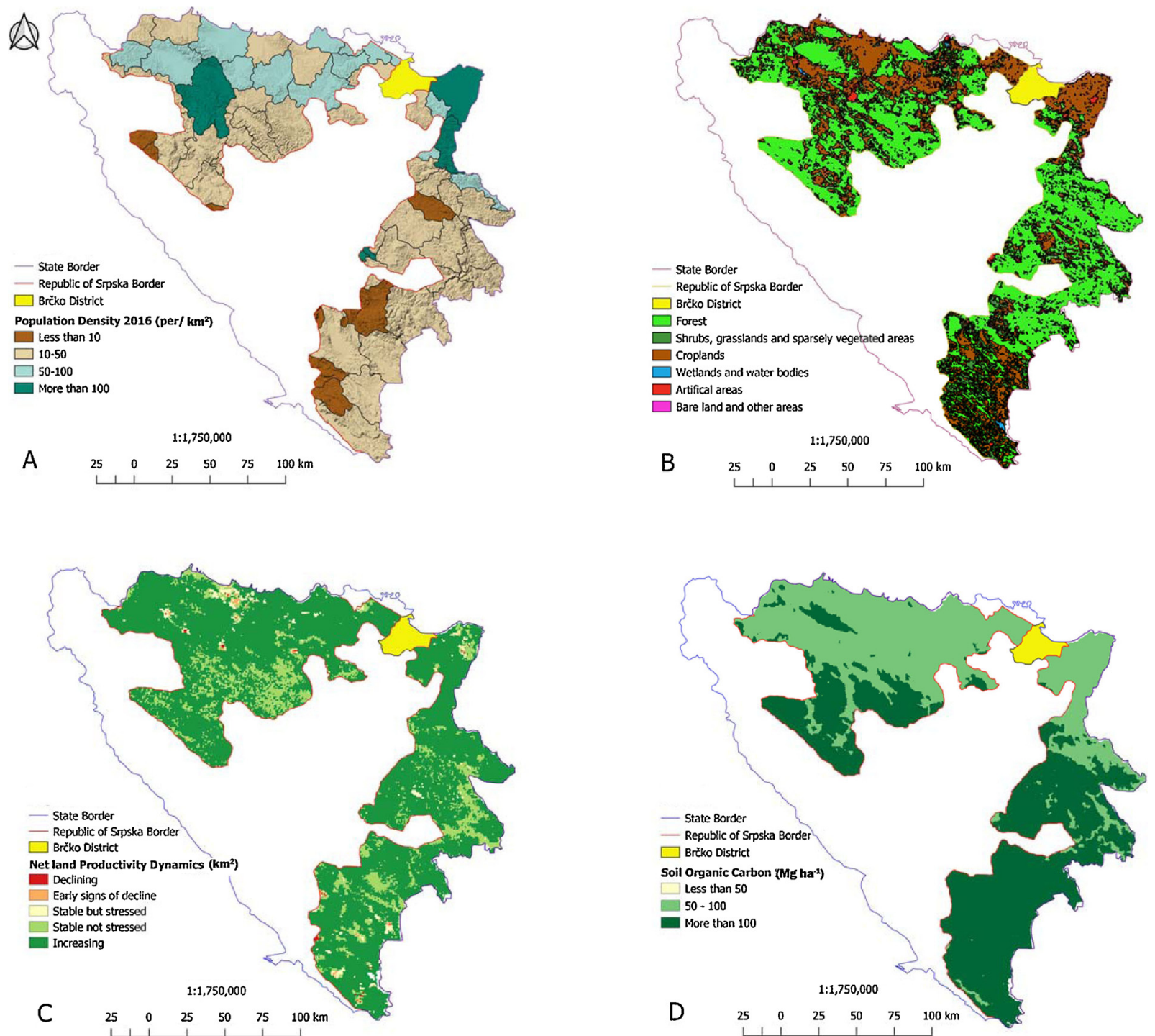

Fig. 2. A) Population density in the RS (2016); B) Land cover in 2010 (ESA, 2010); C) Land Productivity in RS (JRC, 1999-2013); D) Soil Organic Carbon Content (ISRIC, 2010).

land area. Early signs of productivity decline were observed across a limited area $(0.4 \%)$. Stable land under stress was moderately higher than declining productivity areas with $2.0 \%$ of the RS region. Stable land covered $14.9 \%$ of the region. Taken together, the three categories with declining productivity covered $2.5 \%$ of the region (Fig. 2C). Cropland areas showed signs of declining productivity $(72.6 \%$ of agricultural land area with reduced productivity) compared to forests (9.8\%), shrubs (7.6\%) and artificial areas respectively (9.0\%). SOC average content was $104.4 \mathrm{Mg}$ ha $^{-1}$ with a loss of $74.6 \mathrm{Mg} \mathrm{ha}{ }^{-1}$ (15.6\%) when forests were converted to cropland (Table 3). Lower carbon stocks were primarily related to areas of intensive agriculture (north and east part of the RS) with an average of $93.1 \mathrm{Mg} \mathrm{ha}^{-1}$ of carbon. Soils with an average carbon content $100 \mathrm{Mg} \mathrm{ha}^{-1}$ or greater are principally under forests and shrublands (Fig. 2D).

\subsection{Land degradation trends}

Change in land cover appears an important indicator of land degradation, providing a first indication of a reduction or increase in vegetation, habitat fragmentation and land conversion in the study area. Trends in land cover showed a decline in forest cover while shrub cover and cropland area increased across the region. Declines in forest cover appear driven by deforestation of highly productive forests in the mountainous area (illegal logging) and wildfires that are very frequent in the south part of the country. Quality of forest structure decreased over the time (UNDP, 2013, 2016), but that cannot be detected by the proxy indicators of Land Degradation Neutrality selected (see Section 2.2). Increases in shrubs, grasslands and sparsely vegetated areas were mainly a result of abandonment of agricultural land due to migration during the Bosnian War and from rural areas to urban centers (Kapović Solomun et al., 2015). This is consistent with reports by local governments in which $75 \%$ of those surveyed reported encroachment of shrubland on abandoned agricultural land and significant declines in cultivated areas for the last 25 years. Even though land abandonment does not always result in land degradation, and in some areas contributes to land restoration (Cerdà et al., 2018a; Keesstra et al., 2018a; López-Vicente et al., 2017), in the RS this process deteriorates the vegetation cover in terms of vegetation species composition and the land use options.

Land use changes, human-induced pressure and land use intensification are important to understand the land degradation fate of the RS (FAO, 2015), and this fate is similar to other geographies as reported in Alagna et al., (2017); Masselink et al., (2017); Pulido et al., (2017) and Zema et al., (2016). Similarly to other regions of the world, 

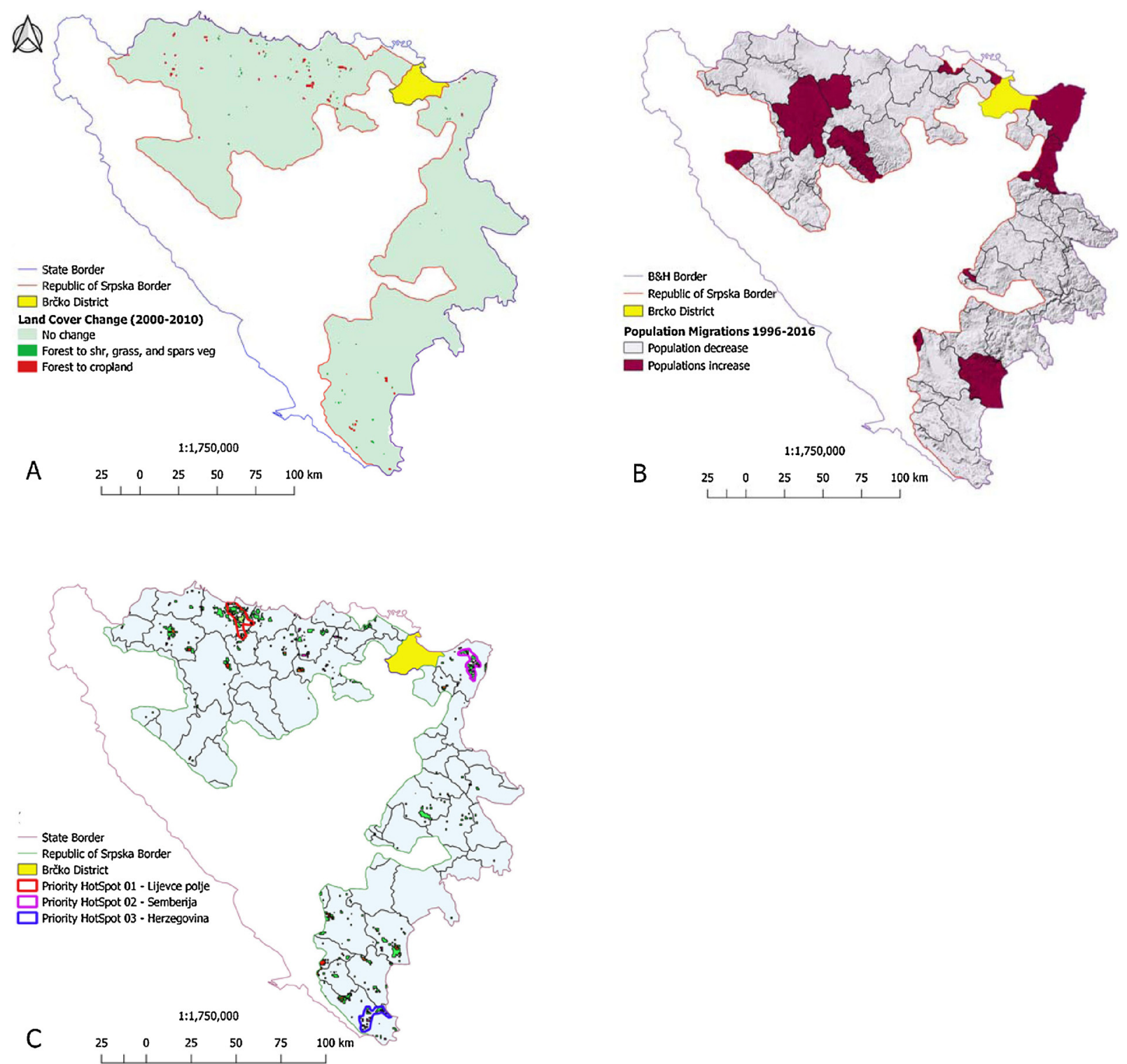

Fig. 3. A) Land cover change (ESA, 2000-2010); B) Population change in the Republic of Srpska (1996-2016); C) LDN "hot spots" in the Republic of Srpska.

abandonment results in contrasted responses that are dependent on the type of crops, climate and restoration actions (Lana-Renault et al., 2018; Rodrigo-Comino et al., 2018); as well as on the degree of control the parent material and soil properties have on post-abandonment
(López-Vicente et al., 2015; Martínez-Hernández et al., 2017). Additionally, extreme events like floods and drought affects the north and north-east parts of the country. Decline in cropland productivity is mostly related to intensive agricultural production that still relies on

Table 2

Presentation of national data for the RS using the LDN indicators framework.

\begin{tabular}{|c|c|c|c|c|c|c|c|c|c|c|}
\hline \multirow[t]{2}{*}{ Land use/cover category } & \multirow{2}{*}{$\begin{array}{l}\text { Area } \\
(2000) \\
\mathrm{km} 2\end{array}$} & \multirow{2}{*}{$\begin{array}{l}\text { Area } \\
(2010) \\
\text { km2 }\end{array}$} & \multirow{2}{*}{$\begin{array}{l}\text { Net area change } \\
(2000-2010) \\
\text { km2 }\end{array}$} & \multicolumn{6}{|c|}{ Net land productivity dynamics (NetLPD) $(\mathrm{km} 2)^{\mathrm{a}}$} & \multirow{2}{*}{$\begin{array}{l}\text { Soil organic } \\
\text { carbon (2000) } \\
\text { Mg ha-1 }\end{array}$} \\
\hline & & & & Declining & $\begin{array}{l}\text { Early signs of } \\
\text { decline }\end{array}$ & $\begin{array}{l}\text { Stable but } \\
\text { stressed }\end{array}$ & $\begin{array}{l}\text { Stable not } \\
\text { stressed }\end{array}$ & Increasing & No Data & \\
\hline Forest & 14,473 & 14,409 & -64 & 1 & 8 & 53 & 2,241 & 12,095 & 11 & 110.0 \\
\hline $\begin{array}{l}\text { Shrubs, grasslands and sparsely } \\
\text { vegetated areas }\end{array}$ & 1,704 & 1,718 & 14 & 6 & 5 & 37 & 282 & 1,372 & 16 & 118.2 \\
\hline Croplands & 8,397 & 8,447 & 50 & 18 & 67 & 376 & 1,102 & 6,822 & 61 & 93.1 \\
\hline Wetlands and water bodies & 92 & 92 & 0 & 0 & 0 & 5 & 19 & 53 & 15 & 86.3 \\
\hline Artificial areas & 355 & 355 & 0 & 13 & 10 & 34 & 94 & 203 & 1 & 83.6 \\
\hline Bare land and other areas & 4 & 4 & 0 & 0 & 0 & 0 & 2 & 1 & 0 & 123.6 \\
\hline SOC average (Mg ha-1) & & & & & & & & & & 104.4 \\
\hline Percentage of total land area & & & & $0 \%$ & $0 \%$ & $2 \%$ & $15 \%$ & $82 \%$ & $0 \%$ & \\
\hline TOTAL (km2) & 25,024 & 25,024 & 0 & 38 & 91 & 506 & 3,739 & 20,547 & 103 & \\
\hline
\end{tabular}

${ }^{a}$ Values for NetLPD and SOC are only for areas where Land Use/Cover is unchanged from 2000 to 2010. 
Table 3

Presentation of soil organic carbon for the RS using the LDN indicators framework.

\begin{tabular}{|c|c|c|c|c|c|c|}
\hline \multirow[t]{2}{*}{ Changing Land Use/Cover Category } & \multirow{2}{*}{$\begin{array}{l}\text { Net area change (2000-2010) } \\
\text { km2 }\end{array}$} & \multicolumn{5}{|c|}{ Soil organic carbon $0-30 \mathrm{~cm}(2000-2010)$} \\
\hline & & $\begin{array}{l}2000 \\
\text { Mg ha-1 }\end{array}$ & $\begin{array}{l}2010 \\
\text { Mg ha-1 }\end{array}$ & 2000 total $(\mathrm{Mg})$ & 2010 total $(\mathrm{Mg})^{\mathrm{a}}$ & 2000-2010 loss (Mg) \\
\hline Forest to Cropland & 50 & 85 & 70 & 422950 & 348341 & -74609 \\
\hline Forest to Shrubs, grasslands and sparsely vegetated areas & 14 & 95 & 95 & 134311 & 134311 & 0 \\
\hline Total & 64 & & & 422950 & 482652 & -74609 \\
\hline
\end{tabular}

a Change in SOC due to changing Land Use/Cover derived from IPCC, 2006.

unsustainable agricultural practices (Kapović Solomun, 2018). Degradation of croplands is further amplified when it coincides with drought, which temporarily but dramatically reduces soil and plant productivity. Increases in land productivity primarily occurred in forest areas that cover $53 \%$ of territory.

Trends in land cover for cropland, proposed by global dataset are not in accordance field based evidence, data of local municipalities and existing statistical data (Statistical Journal, 2009, 2017). Global trends report increase in cropland for ten years (2000-2010), while statistical data show decrease in cropland area over 17 years (2000-2017). Also, local communities targeted abandoned cropland as a major land degradation driver from economic perspective, even though abandonment enhance biodiversity restoration sometimes. Another incongruity of the global data is identified for areas with very shallow and skeletal soils on limestone and dolomite, wide spread in central but particularly in south part of the region. Lower carbon stocks are expected in southern part of the $\mathrm{RS}(\mathrm{BiH})$ than it is shown from the global data, due to prevalence of bare land, skeletal and shallow soils on limestone and dolomite substrate (United Nations Environmental Programme (UNEP), 2017).

\subsection{Drivers of land degradation}

Local community perspectives obtained through interviews were important in identifying land degradation drivers in the RS, which is in line with bottom-up implementation, and involvement of local populations as a prerequisite to implement the UNCCD convention (UNCCD, 2012). Land resources are under constant anthropogenic pressure at the local level, where depending on region, different land degradation drivers were targeted. Local stakeholders in 31 municipalities were gathered, consulted and actively engaged in LDN target setting process (Table $1 \mathrm{SI}$ ). From these interviews it emerges that depopulation and internal migrations are the two underlying drivers of land degradation that resulted in abandoned agricultural land over the last 25 years; which in turn becomes vulnerable to colonization by invasive species and degradation. The strong human influence and degradation of natural ecosystems causes frequent occurrence and expansion of invasive species, which leads to imbalances among abiotic and biotic ecological factors, expansion of plant diseases and disruption of human health (Mahmutović-Dizdarević and Grabovac, 2015). Based on available records (Vojniković, 2015), it is estimated that more than 500 invasive species occur in the territory of Bosnia and Herzegovina, and a significant number of them live in cropland, especially abandoned one (Redžić et al., 2008). A clear weakness that emerged in the use of the three LDN indicators was the inability to identify land degradation due to invasive species.

Generally, the most frequent direct drivers of land degradation across this region were land abandonment, floods, drought, erosion and urbanization, which are underpinned by the lack of responsible land use planning by local communities where majority of them do not have local strategic documents for land use planning, despite legal obligations in this regard. Accelerated and aggressive urbanization of Banja Luka, Bijeljina, Zvornik, Prijedor and East Sarajevo is caused by internal migration to urban areas (Kapović Solomun, 2018). Excessive, illegal deforestation and wildfires contribute to degradation of forest land and it is conductive to erosion and landslides. Rural municipalities have been struggling with economic survival in the transition process where sustainable land management is of secondary importance.

Low lying agricultural regions are also vulnerable to floods. Extreme events like floods and/or drought frequently affect agricultural communities especially in Semberija and Posavina. Climate change forecasted for the study area will increase flooding events given changes in precipitation (United Nations Environmental Programme (UNEP), 2017; Kapović et al., 2013) and other human induced drivers like excessive illegal deforestation in the vicinity of water sources (Marković, 2017), or changes in the forest type due to afforestation (Maunaga and Dukić, 2014). As well, climate change, through those extreme events, can affect change in land productivity even land type (O'Connell et al., 2015), which is a common situation in the north of region. Unsustainable agricultural practices and techniques, uncontrolled use of pesticides and mineral fertilizers lead to the occurrence of erosion and soil degradation in every sense. Urban areas facing growth of the population and frequent change of most fertile agricultural into construction land for the purpose of urbanization. Rural municipalities have been struggling mostly with economic survival in transition process where sustainable land management is of secondary importance (Kapović Solomun, 2018). Illegal construction is common practice. Mining activities are under entity jurisdiction, and the approach is to strengthening the national economy rather than protect environment. Devastated post-mining sites and landscapes are a frequent picture on the ground. Also, landfills and land contamination pose a particular problem. Awareness of land importance of stakeholders and local decision-makers are generally at a low level, but farmers were very interested and questionable about new knowledge and possible land practices that will sustain its land productivity.

\subsection{Priority land degradation "hot spots"}

The selected LDN indicators dataset identified areas with decreased land productivity within the country. Potentially degraded areas were validated in the field and three "hot spots" were identified as in need of urgent intervention. The LDN working group discussed this proposal considering the socio-economic aspects: level of community development, number of inhabitants in each local community, existing State, Entity and local strategic documents and priorities for investments, important agricultural regions for production, urbanization pressure, vulnerable ecologic conditions (karst areas in Herzegovina), equal regional economic development, migrations and population density. The integration of environmental and socio-economic aspects placed Herzegovina, Semberija and Lijevče polje (Fig. 3C) as places of highest priority for future interventions. Every year Herzegovina region is affected by large number of wildfires which destroy rare vegetation and additionally degrade already poor soil cover, contributing to bare land expansion. Uneven distribution of precipitation during the year, where only $30 \%$ fall in the spring-summer period, causes drought, but also water surplus over the winter in karst fields. Water management and bare land in the Herzegovina are a burning problems. Soils under extreme conditions such as karst, require more careful forest management systems, adapted to environmental, more than economic requirements. 
Afforestation is the most important and feasible measure needed for land and water protection, based on careful selection of seedlings of highest quality adapted to karst conditions. Successful reforestation is conceived as a triple win solution to regain ecological integrity, enhance human well-being in deforested or degraded landscapes and resilience to climate change. The Semberija and Lijevče polje are very important agricultural regions and backbones of rural households' economic development of the Republic of Srpska. Land productivity decrease is a consequence of several land degradation drivers, where frequent drought and floods, are identified as natural drivers on one side, and loss of organic matter, uncontrolled usage of pesticides, mineral fertilizers and soil compaction as human induced drivers on the other. Functional and modern irrigation/drainage system would increase agricultural yield, reduce exceedingly usage of pesticides and mineral fertilizers and combat drought at the same time (Hodzic et al., 2013; Zurovec and Cadro, 2010). Farmers of these regions were particularly interested for education and knowledge about sustainable land management and other possible measures that will help them to increase organic matter level, decrease existing over usage of fertilizers and pesticides and ensure sustainability of their land. The Ministry of Agriculture, Forestry and Water management of the RS committed to this proposal aimed to implementation of appropriate SLM measures that will additionally contribute to achievement of LDN.

\section{Issues for target setting in a developing country}

The LDN target setting process was challenging for the RS due to the complex political structure and administration, which directly complicates decisions, policies, planning and implementation of land rehabilitation measures. The Constitution of the RS gives the RS legal rights to create land policy, including planning, rehabilitation and land use. The Ministry of Agriculture, Forestry and Water Management is the key institution responsible for the agriculture, forestry, water and veterinary management, while the Ministry of Spatial planning, Construction and Ecology of the RS is responsible for physical land planning and construction. The Ministry of Industry, Energy and Mining of the RS addresses issues related to mining and industrial plants that certainly have an impact on the land resources. Existing inter-sectoral dialogue and cooperation in land issues is not well-developed and there is a clear need for a more integrated approach. The LDN target setting process often faced opposing opinions among institutions managing the same land. Considering natural and socio-economic diversity, the LDN working group first proposed LDN targets on a regional level based on climate characteristics. This approach, however, was not supported by the above mentioned institutions due to administrative complexities implementing LDN targets based on environmental characteristics. Existing national data for land cover/use, rely on outdated cadastral data which is highly uncertain in estimating land cover changes or trends. On the other hand, global trends for some land cover categories may also be uncertain. On the other hand, the global trend for cropland is maybe correct, but due to different times scale and periods of observation, recent land degradation drivers are differed than the time period in which the global data are reported (2000-2010). For example, local communities voiced their concerns related to cropland decrease due to land abandonment. However, the global data suggests that croplands were increasing. Also, it is often the case that public institutions do not want to share their land related data that could be used for the review. Without reliable national data, however, countries do not have other choices except to use global data for setting the LDN baseline, target and associate measures for achieving LDN. Establishing the LDN baseline in this way involves uncertainties in the whole process and estimations about the amount of actual land degradation in the RS. What is clear is that stakeholder consultations showed that land degradation is not a priority, which strongly contributed to the difficulties in navigating the LDN process.

\section{Concluding remarks}

Legislation in the RS generally recognizes and incorporates sustainable land management, where land protection is regulated by multiple sectoral regulations. Inconsistent implementation of existing legal obligations is a more important barrier to LDN implementation than absence of law on land protection. Institutional exchange of information, data and system of coordination on all levels is not satisfactory since there is no official regulatory mechanism on this matter. The neutrality mechanism should be implemented at the resolution of the biophysical or administrative spatial domain of land use planning and decision making. Ideally, neutrality would be integrated into existing land use planning processes, and implemented by existing institutions (Cowie et al., 2018). Thus, consistent application of the existing laws together with comprehensive system of control is prerequisite for achievement of LDN in this region.

Common land degradation drivers are population and economic growth, but this is not the case for the RS (BiH), which is facing intensive depopulation. On the other hand, economies of developing countries usually rely on natural resources, so the connection between soil quality and "natural economy branches" like forestry (Bergquist and Keskitalo, 2016), agriculture (Herrick, 2000), and tourism (Kowalska et al., 2016) is obvious. A majority of local communities in the region have experienced depopulation, especially in rural economies that tend to be natural resource dependent and reliant on agriculture, forestry, tourism and recreation (Kreibich et al., 2015; Hales et al., 2014; Lal et al., 2011). Unsustainable use of natural resources common in the RS are excessive deforestation, exploitation of mineral resources, uncontrolled urbanization and inadequate practices in agriculture. Drinking water sources are often endangered in areas with climate change on stage and frequent extreme events like frequent floods, drought and wildfire. Abandoned agricultural land, depopulation of rural areas, weeds expansion and mine contamination are a reality in a post war environment. There is no national data about exact permanent loss of land in urban areas due to illegal construction or legal urbanization which contributes to the emergence of landslides, endangered natural habitats and so on. Existing land planning system on local level is very weak and without "avoid and reduce land degradation" approach. National land related strategies and studies usually do not include land and private forests owners, especially land user's experiences in assessing land degradation.

Socio-economic transitions, complex political and administration environment in developing countries are another real challenge in implementation of LDN in countries like BiH. Low level of knowledge and awareness about land degradation is apparent, specifically in depopulated municipalities where land management is of secondary importance.

To overcome these challenges, and based on the findings of LDN target setting in the RS, we propose:

1 Consistent implementation of the existing legislative framework, strengthen the system of control; and stronger cooperation between institution in terms of land data exchange, regulated by an official Agency,

2 Institutionally driven implementation of LDN and introduction of new sustainable land measures (e.g. riparian buffers, agroforestry) with active participation of land owners/users would significantly accelerate the LDN processes;

3 Development of a national Strategy for Land protection as an opportunity to avoid land degradation and implement initiatives conducive to achieve land degradation neutrality;

4 Introduction of an "avoid and reduce land degradation" on local planning system and encourage local governments to develop land use plans as a legal obligation;

5 Establishment of unified land information systems and land monitoring with additional national indicators linked to climate 
conditions, followed by updated land cadaster and land-oriented planning systems;

6 Connect existing traditional land knowledge to modern approaches and technology;

7 Balanced socio-economic development focused on depopulated local communities,

8 Awareness raising in general, but especially at local level is a necessary second step needed for successful implementation of LDN, specifically in depopulated municipalities where land management is of secondary importance.

\section{Acknowledgment}

The authors gratefully acknowledges the editors of this special issue of the "Environmental Science and Policy" and reviewers. The paper was developed within the framework of "Land Degradation Neutrality Target Setting Process in the Republic of Srpska" supported by United Nations Convention to Combat Desertification, Ministry of Agriculture, Forestry and Water Management of the RS (MAFWM), LDN working group members and local communities of the RS.

\section{Appendix A. Supplementary data}

Supplementary material related to this article can be found, in the online version, at doi:https://doi.org/10.1016/j.envsci.2018.09.014.

\section{References}

Alagna, V., Di Prima, S., Rodrigo-Comino, J., Iovino, M., Pirastru, M., Keesstra, S.D., Cerdà, A., 2017. The impact of the age of vines on soil hydraulic conductivity in vineyards in eastern Spain. Water $10(1), 14$.

Bergquist, A.K.H., Keskitalo, E.C., 2016. Regulation versus deregulation. Policy divergence between Swedish forestry and the Swedish pulp and paper industry after the 1990. For. Policy Econ. 73, 10-17.

Cadastre, 2016. Katastar šuma i šumskog zemljišta Republike Srpske, 2016. JPŠ "Šume Republike Srpske" a.d. Sokolac (Cadastre of forests and forest land of the Republic of Srpska, 2016. PFE "Forests of the Republic of Srpska "a.d. Sokolac)

Cerdà, A., Rodrigo-Comino, J., Giménez-Morera, A., Novara, A., Pulido, M., KapovićSolomun, M., Keesstra, S.D., 2018. Policies can help to apply successful strategies to control soil and water losses. The case of chipped pruned branches (CPB) in Mediterranean citrus plantations. Land Use Policy 75, 734-745.

Cerdà, A., Rodrigo-Comino, J., Novara, A., Brevik, E.C., Vaezi, A.R., Pulido, M., GiménezMorera, A., Keesstra, S.D., 2018a. Long-term impact of rainfed agricultural land abandonment on soil erosion in the Western Mediterranean basin. Prog. Phys. Geogr. 42, 202-219. https://doi.org/10.1177/0309133318758521.

Cowie, A., Orr, B., Castillo Sanchez, V., Chasek, P., Crossman, N., Erlewein, A., Louwagie, G., Maron, M., Metternicht, G., Minelli, Sara, Tengberg, A., Walter, S., Welton, S. 2018. Land in balance: the scientific conceptual framework for Land Degradation Neutrality. Environ. Sci. Policy 79, 25-35. https://doi.org/10.1016/j.envsci.2017.10. 011.

European Space Agency, 2010. Climate Change Initiative Land Cover Datasets (2000-2010). ESA-CCI-LC. http://www.esa-landcover-cci.org.

FAO, 2015. The Forest Sector in Bosnia and Herzegovina - Preparation of IPARD Forest and Fisheries Sector Reviews in Bosnia and Herzegovina. Regional Office for Europe and Central Asia, FAO, Rome.

Hales, D., Hohenstein, W., Bidwell, M.D., et al., 2014. Chapter 14 rural communities. In: Melillo, J.M., Richmond, T.C., Yohe, G.W. (Eds.), U.S. Global Change Research Program, pp. 333-349.

Herrick, J.E.K., 2000. Soil quality: an indicator of sustainable land management? Appl. Soil Ecol. 15, 75-83. https://doi.org/10.1016/S0929-1393(00)00073.

Hodzic, S., Markovic, M., Custovic, H., 2013. Drought Conditions and Management Strategies in Bosnia and Herzegovina-Concise Country Report. Available online. http://www.ais.unwater.org/ais/pluginfile.php/548/mod_page/content/72/Bosnia Herzegovina_CountryReport.pdf.

Intergovernmental Panel on Climate Change (IPCC), 2006. Good Practice Guidance (GPG) for Land use, Land Use Change and Forestry (LULUCF). https://www.ipcc-nggip.iges. or.jp/public/gpglulucf/gpglulucf_files/GPG_LULUCF_FULL.pdf.

International Soil Reference and Information Centre (ISRIC), 2010. Datasets for 2000. http://www.isric.org/content/soilgrids.

Joint Research Centre of the European Commision (JRC), 2016. Datasets for 1999-2013. http://www.stapgef.org/stap/wp-content/uploads/2015/03/Michel-CherletRemote-sensing-products-and-globaldatasets.pdf.

Kapović, M., Tošić, R., Knežević, M., Lovrić, N., 2013. Assessment of soil properties under degraded forests - case study: Javor mountain - Republic of Srpska. Arch. Biol. Sci. 65 (2) Belgrade.

Kapović Solomun, M., 2018. Program dostizanja neutralnosti degradacije zemljišta u Republici Srpskoj, Banja Luka (Final report on Land Degradation Neutrality Target
Setting Program in the Republic of Srpska, Banja Luka). . http://www.vladars.net/srSP-Cyrl/Vlada/Ministarstva/mps/Documents/LDN\%20TSP\%20Report\%20za \%20Republiku\%20Srpsku_470474363.pdf.

Kapović Solomun, M., Eremija, S., Gavrić, Z., 2015. Karakteristike i ekološko - proizvodni potencijal zemljišta na serpentinitima u PJ,Donja Velika Usora“, Glasnik Šumarskog fakulteta, Univerzitet u Banjoj Luci, Broj 23, str. 85-93, Banja Luka (Characteristics and ecological-productive potential of the serpentine soils in forest economic area "Donja Velika Usora") Bulletin of the Faculty of Forestry, University of Banja Luka, No. 23, pp. 85-93, Banja Luka. doi: 10.7251/GSF1523085K, COBISS.RS-ID: 5561624.

Keesstra, S.D., Bouma, J., Wallinga, J., Tittonell, P., Smith, P., Cerdà, A., Montanarella, L., Quinton, J.N., Pachepsky, Y., Van Der Putten, W.H., Bardgett, R.D., Moolenaar, S., Mol, G., Jansen, B., Fresco, L.O., 2016. The significance of soils and soil science towards realization of the United Nations sustainable development goals. Soil 2, 111-128. https://doi.org/10.5194/soil-2-111-2016.

Keesstra, S., Nunes, J., Novara, A., Finger, D., Avelar, D., Kalantari, Z., Cerdà, A., 2018a. The superior effect of nature based solutions in land management for enhancing ecosystem services. Sci. Total Environ. 610-611. https://doi.org/10.1016/j. scitotenv.2017.08.077.

Kowalska, J., Mazurek, R., Gąsiorek, M., Setlak, M., Zaleski, T., Waroszewski, J., 2016. Soil pollution indices conditioned by medieval metallurgical activity - a case study from Krakow (Poland). Environ. Pollut. 18, 1023-1036. https://doi.org/10.1016/j. envpol.2016.08.053.

Kreibich, H., Bubeck, P., Van Vliet, M., et al., 2015. A review of damage-Reducing easures to manage fluvial flood risks in a changing climate. Mitig. Adapt. Strategies Glob. Change 20 (6), 967-989.

Lal, P., Alavalapati, J.R., Mercer, E.D., 2011. Socio-economic impacts of climate change on rural United States. Mitig. Adapt. Strategies Glob. Change 16 (7), 819-844.

Lana-Renault, N., López-Vicente, M., Nadal-Romero, E., Ojanguren, R., Llorente, J.A., Errea, P., Pascual, N., 2018. Catchment based hydrology under post farmland abandonment scenarios. Cuad. Investig. Geogrãjfica 43 (1), 83-100.

Liniger, H., Mekdaschi Studer, R., Hauert, C., Gurtner, M., et al., 2011. Sustainable Land Management in Practice. Guidelines and Best Practices for Sub-Saharan Africa. TerrAfrica, Swiss Agency for Development and Cooperation (SDC), World Overview of Conservation Approaches and Technologies (WOCAT), Food and Agriculture Organization of the United Nations (FAO).

López-Vicente, M., Nadal-Romero, E., Cammeraat, E.L.H., 2017. Hydrological Connectivity Does Change Over 70 Years of Abandonment and Afforestation in the Spanish Pyrenees. L. Degrad. Dev. 28. https://doi.org/10.1002/ldr.2531.

López-Vicente, M., Quijano, L., Gaspar, L., Palazón, L., Navas, A., 2015. Severe soil erosion during a 3-day exceptional rainfall event: combining modelling and field data for a fallow cereal field. Hydrol. Process. 29 (10), 2358-2372.

Mahmutović-Dizdarević, I., Grabovac, Z., 2015. Invazivne vrste kao indikator stepena degradiranosti ekosistema na području bosne i hercegovine. Zbornik Radova Sa Trećeg Naučno-Stručnog Skupa Sa Međunarodnim Učešćem 137-146 (Invasive species as indicator of ecosystem degradation in Bosnia and Herzegovina. In Proceedings of the Third Scientific-Expert Conference with international participation, Bihać, Bosnia and Herzegvoina, June 5 2015; pp:137-146).

Marković, M., 2017. Overview of the natural resource management in Bosnia and Herzegovina. In: Dragovic, N., Ristic, R., Pülzl, H., Wolfslehner, B. (Eds.), Natural Resource Management in Southeast Europe: Forest, Soil and Water. Deutsche Gesellschaft für Internationale Zusammenarbeit (GIZ) GmbH, Skopje, pp. 87-130 ISBN: 978-608-4536-07, Chapter 2.

Martínez-Hernández, C., Rodrigo-Comino, J., Romero-Díaz, A., 2017. Impact of lithology and soil properties on abandoned dryland terraces during the early stages of soil erosion by water in south-east S pain. Hydrol. Process. 31 (17), 3095-3109.

Masselink, R., Temme, A.J.A.M., Giménez, R., Casalí, J., Keesstra, S.D., 2017. Assessing hillslope-channel connectivity in an agricultural catchment using rare-earth oxide tracers and random forests models. Cuadernos de Investigación Geográfica 43 (1), 17-39.

Maunaga Z., Dukić, V., 2014. Analiza i ocjena gazdovanja šumama: Kritički osvrt na šumsko-privredne osnove, Glasnik Šumarskog fakulteta Univerziteta U Banjoj Luc broj 21, str. 87-107, Banja Luka (Analysis and evaluation of forest management: a critical review of the forest management plans, Bulletin of the Faculty of Forestry, University of Banja Luka, No.21, pp.87-107, Banja Luka). doi: 10.7251/ GSF1421087M.

Motavalli, P., Nelson, K., Udawatta, R., Jose, S., Bardhan, S., 2013. Global achievements in sustainable land management. Int. Soil Water Conserv. Res. J. 1, 1-10. https://doi. org/10.1016/S2095-6339(15)30044-7.

O'Connell, D., Walker, B., Abel, N., Grigg, N., 2015. The Resilience, Adaptation and Transformation Assessment Framework: From Theory to Application. CSIRO, Dickson, ACT, Australia.

Pulido, M., Schnabel, S., Contador, J.F.L., Lozano-Parra, J., Gómez-Gutiérrez, Á., Brevik, E.C., Cerdà, A., 2017. Reduction of the frequency of herbaceous roots as an effect of soil compaction induced by heavy grazing in rangelands of SW Spain. Catena 158, 381-389.

Redžić, S., Barudanović, S., Radović, M., 2008. Bosnia and Herzegovina - Land of Diversity. Overview and Status of Biological and Landscape Diversity in Bosnia and Herzegovina. Federal Ministry of Environment and Tourism, Sarajevo.

Rodrigo-Comino, J., Martínez-Hernández, C., Iserloh, T., Cerdà, A., 2018. The contrasted impact of land abandonment on soil erosion in Mediterranean agriculture fields. Pedosphere 28 (4), 617-631. https://doi.org/10.1016/S1002-0160(17)60441-7.

A) Population density in the RS IN 2016 (ref: Census, 2013)- Ref: Census of population, households and dwellings in the REpublic of Srpska, 2013. Institute for Statistics of the Republic of Srpska, Banja Luka. http://www.rzs.rs.ba/front/article/2464/.

Schwilch, G., Hessel, R., Verzandvoort, S. (Eds.), 2012. Desire for Greener Land. Options for Sustainable Land Management in Drylands. University of Bern-Centre for 
Development and the Environment (CDE), Alterra-Wageningen UR, ISRIC-World Soil Information, and CTA-Technical Centre for Agricultural and Rural Cooperation, Bern, Switzerland, and Wageningen, the Netherlands.

Statistical Journal, 2009. Statistički godišnjak za poljoprivredu i ribarstvo, Broj 8. Republički zavod za statistiku Republike Srpske, Banja Luka. (Statistical Journal of Agriculture and Fishery No 8, Institute for Statistics of the Republic of Srpska, Banja Luka).

Statistical Journal, 2017. Statistički godišnjak za poljoprivredu i ribarstvo, Broj 16. Republički zavod za statistiku Republike Srpske, Banja Luka (Statistical Journal of Agriculture and Fishery No 16, Institute for Statistics of the Republic of Srpska, Banja Luka).

The Basics, 2009. Osnove Zaštite, Korišćenja I Uređenja Poljoprivrednog Zemljišta Republike Srpske, Kao Komponente Procesa Planiranja Korišćenja Zemljišta, 2009. Poljoprivredni institut Republike Srpske, Banja Luka (The Basics for protection, usage and management of agricultural land of the Republic of Srpska, as component of land use planning process, 2009. Institute of Agriculture of the Republic of Srpska, Banja Luka).

United Nations Convention to Combat Desertification (UNCCD), 2012. Fact Sheet Participatory Development: a Bottom-up Approach to Combating Desertification. UNCCD, Bonn, Germany. http://www.unccd.int/Lists/SiteDocumentLibrary/ Publications/Fact_sheet_06eng.pdf.

United Nations Convention to Combat Desertification (UNCCD), 2014. Land Degradation Neutrality: Resilience at Local, National and Regional Levels. UNCCD, Bonn, Germany.

United Nations Convention to Combat Desertification (UNCCD), 2016. Land Degradation Neutrality Target Setting - a Technical Guide. UNCCD, Bonn, Germany.

United Nations Development Programme (UNDP), 2013. Climate Change Adaptation and Low-emission Development Strategy for Bosnia and Herzegovina. http://www.ba. undp.org/content/bosnia_and_herzegovina/en/home/library/environment_energy/ climate-change-adaptation-and-low-emission-development-strategy-.html.

United Nations Development Programme (UNDP), 2016. Third National Communication and Second Biennial Update Report on Greenhouse Gas Emissions of Bosnia and Herzegovina Under the United Nations Framework Convention on Climate Change. UNDP, Sarajevo, Bosnia and Herzegovina. http://www.ba.undp.org/content/bosnia and_herzegovina/en/home/library/environment_energy/tre_i-nacionalni-izvjetajbih.html.

United Nations Environmental Programme (UNEP), 2017. Action Program for Combat Land Degradation and Mitigate the Effects of Drought in Bosnia and Herzegovina. UNEP, Sarajevo, Bosnia and Herzegovina. http://www.unep.ba/tl_files/unep_ba/ PDFs/BHAP_eng_FINAL.pdf.

Vojniković, S., 2015. Tall cone flower (Rudbeckia laciniata L.) - new invasive species in the flora of Bosnia and Herzegovina. Herbologia 15 (1), 39-47.

Witmer, F., O'Loughlin, J., 2009. Satellite data methods and application in the evaluation of war outcomes: abandoned agricultural land in Bosnia-Herzegovina after the 19921995 conflict. Ann. Assoc. Am. Geogr. 99 (5), 1033-1044.

WRB: World Reference base for soil resources, 2006. World Soil Resources Reports, No 103. 2nd edition. Food and Agriculture Organization of the United Nation, Rome

Zema, D.A., Denisi, P., Taguas Ruiz, E.V., Gómez, J.A., Bombino, G., Fortugno, D., 2016. Evaluation of surface runoff prediction by a nn AGNPS model in a large mediterranean watershed covered by olive groves. Land Degrad. Dev. 27 (3), $811-822$.

Zurovec, J., Cadro, S., 2010. Climate changes, the need and importance of crop irrigation in northeastern Bosnia and Herzegovina. Proceedings of the 21st Scientific-Expert Conference in Agriculture and Food Industry 705-716.

Marijana Kapović Solomun, PhD in Forestry (University of Belgrade, Serbia), Assistant Professor at Faculty of Forestry of University of Banja Luka. Her main areas of interest are forest soils, environment, land degradation and conservation. She is member of UNCCD SPI, and founder of women association for nature protection, having participated in more than 15 national and international projects in environment area, as a project leader or expert for soil. She is published more than 30 papers in national or international journals.

Nichole Barger, PhD in Ecology (Colorado State University, USA), Associate Professor at Department of Ecology and Evolutionary Biology University of Colorado. Her main research areas are sustainable land management and restoration of a broad variety of ecosystems throughout the world. Her research mission is better understand the fundamental ecological processes that influence the structure and function of dryland ecosystems and the resilience of these ecosystems to human and natural disturbance. She is Coordinating Lead Author at the IPBES and UNCCD SPI member. She published more than 50 scientific papers published in international Journals.

Artemi Cerdà, $\mathrm{PhD}$ in Physical Geography (University of Valencia, Spain), Full Professor at Department of Geography, University of Valencia and Head of the Soil Erosion and Degradation Research Team. His main areas of interest are forest and agriculture soils, land degradation, soil conservation and land restoration. He is member actively organizing scientific and stakeholder meetings, coordinating research projects and teaching. After 20 research projects and more than 200 scientific papers Artemi Cerdà is developing an international scientific and teaching program with Iran, USA, The Netherlands, UK, Argelia, Italy, Greece and Australia.

Saskia Keesstra, PhD in Physical Geography (Vrije Universiteit Amsterdam, The Netherlands). Senior Researcher at Wageningen University and Research and conjoint associate Professor at the University of Newcastle, Australia. Her main interests in research are: Catchment system dynamics: Using process knowledge for sustainable development. She works on understanding catchment system dynamics in a holistic way to empower sustainable land and river management and mitigate soil threats with the help of nature's forces. Interaction with stakeholders is essential to come to usable, acceptable tools for sustainable land management to achieve the Sustainable Development Goals. She has more than 90 scientific papers published in international peer reviewed Journals.

Mihajlo Marković, PhD in Soil Science, (University of Banja Luka). Full professor of soil science, soil melioration and soil protection, Department of Soil and Water, Faculty of Agriculture, University of Banja Luka. Main areas of interest are agriculture soils, melioration, soil and water, land degradation and erosion. He was UNCCD National focal point for $\mathrm{BiH}$ for 10 years, leader of more than 40 research national and international projects, and author or co-author of more than 100 scientific papers. 